IdeAs

Idées d'Amériques

$1 \mid 2011$

Intégrations dans les Amériques

\title{
Broken Promises? NAFTA, Immigration, and 'Shadow' Regionalism
}

Promesses Rompues? L'ALENA, l'immigration et le régionalisme informel

¿Promesas incumplidas? El TLCAN, la inmigración y el regionalismo informal

\section{Fanny Lauby}

\section{(2) OpenEdition}

\section{Journals}

Electronic version

URL: https://journals.openedition.org/ideas/156

DOI: 10.4000/ideas. 156

ISSN: 1950-5701

\section{Publisher}

Institut des Amériques

Electronic reference

Fanny Lauby, "Broken Promises? NAFTA, Immigration, and 'Shadow' Regionalism", IdeAs [Online], 1

2011, Online since 31 August 2011, connection on 19 October 2022. URL: http://

journals.openedition.org/ideas/156; DOI: https://doi.org/10.4000/ideas. 156

This text was automatically generated on 19 October 2022

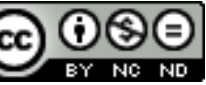

Creative Commons - Attribution-NonCommercial-NoDerivatives 4.0 International - CC BY-NC-ND 4.0 https://creativecommons.org/licenses/by-nc-nd/4.0/ 


\title{
Broken Promises? NAFTA, Immigration, and 'Shadow' Regionalism
}

\author{
Promesses Rompues? L'ALENA, l'immigration et le régionalisme informel \\ ¿Promesas incumplidas? El TLCAN, la inmigración y el regionalismo informal
}

Fanny Lauby

The North American Free Trade Agreement (NAFTA) is not an immigration agreement, but both the American and Mexican governments relied implicitly on the idea that the stimulation of the Mexican economy could curb immigration to the United States. Yet today the situation has not changed for the better, considering not only the increase in immigration since the mid-1990s, but also its large share of unauthorized bordercrossings. At the time the agreement was signed, in preparation for the expected shortterm increase in immigration, the United States launched several operations to try to strengthen its control of the border. Yet even if these operations have rendered the border more difficult to cross, they have failed to produce the deterrent effect that had been wished for. Indeed, the change brought by these actions has not been to reduce the number of people crossing the border, but to decrease the number of temporary migrations through which seasonal laborers returned to Mexico after the harvesting or construction season. The result of this new immigration pattern has been a sharp increase in the number of unauthorized immigrants choosing to stay in the United States, and therefore a growth of the undocumented population to about 11 million people (Passel and Cohn, 2010).

2 This growth has only been matched by the increase in remittances sent from the United States to Mexico and Central American countries. The amount sent in 2007 reached 26 billion dollars (MIF, 2009), and has only decreased slightly since then. As more migrants find their way to the U.S. labor market and the sending of remittances is facilitated by the liberalization of trade between the two countries, we can observe the development of a parallel 'integrated' region where "people move north and money moves south" (Suro, 2003: 5) and which shadows the regionalism planned by NAFTA. 
This new region encompasses Mexico and the entire United States. If the goals of NAFTA in terms of immigration were not met, the liberalization of trade and the increase in travel between the U.S. and Mexico has led to the development of a 'shadow' regional system outside of the realm of competence of the agreement, but which in its own way brings benefits to both partners.

\section{NAFTA and the U.S. - Mexico immigration system}

\section{Migrants as central agents of the regional system}

3 The regional system developed in parallel with the North American Free Trade Agreement is one that was created by migrants themselves, through their own movements and exchanges across the border. The literature on transnational studies has increasingly shown the positive role that migrants themselves can play as agents of transnational development (Faist, 2008; Kapur, 2004). The economic regionalism promoted by NAFTA was designed and set up by states and other institutional actors. Through the lens of transnationalism, it becomes possible to study the lives and actions of migrants in the region, particularly those of unauthorized migrants, and to see these experiences as the basis for a form of "shadow" regionalism that has emerged as an unintended consequence of the trade agreement. According to Faist (2008), states are limited by their clear territorial borders, unlike markets and communities which can develop across them. This "shadow" system also includes a darker aspect of the lives of migrants - their exploitation by human traffickers, smugglers and organized crime. This view allows us to consider a new migration and economic system encompassing Mexico and the entire United States, from California through the mid-West to the South.

4 The role of migrants is central in the establishment of a regional "system" parallel to the economic integration of NAFTA. As a new focus for transnational studies, migrant practices are seen in a more positive light, and are now understood not just as an experience in the host country, but also in relations to their home country (Levitt and Jaworsky, 2007). This conception of a social space across borders, which is carried on by migrants rather than states and institutions, is increasingly common in the literature, as exemplified by Roger Smith's Mexican New York (2006). His account of the lives and experiences of Mexican migrants between New York and Mexico shows not only new strategies for personal economic development and social mobility, but also the transformation of each social and geographical space migrants access. By placing migrants at the center of the creation of the new system, the transnational focus invites us to look at their habits, their movements, their use of technology (Waldinger, 2007) and at their financial operations across borders. According to Vertovec (2004), the new direction of the literature on transnational practices has made the transformation of space and regions a greater point of interest than local change. The use of the transnational lens allows us to focus on deep processes of transformation that are already ongoing, rather than focus on one particular locality. Thus the establishment of a "shadow" region can be understood as the transformation of institutions and practices by migrants themselves, as they maintain transnational practices between the United States and Mexico. It is those practices, and particularly unauthorized migration and remittances, that we will use here to understand how the 
combination of the pre-existing US-Mexico migratory system and the effects of NAFTA have contributed to the transformation of the region.

\section{The secondary goal of reducing immigration}

NAFTA is a commercial treaty that covers the exchange of goods, services and capital between the United States, Mexico and Canada, but unlike other regional integration treaties - such as the Maastricht Treaty in Europe - it does not mention the movement of persons within that region. Yet it was thought to bring some benefits in areas beyond the economic and financial spheres. More specifically, one common assumption was that increasing trade flows between the United States and Mexico would eventually reduce immigration from the latter to the former. According to Gustavo Flores-Macías (2008: 436), those who drafted the treaty relied on a 'classical international trade theory' in which the increase in trade flows would reduce the number of immigrant workers coming from Mexico. The idea was that Mexico would concentrate on developing labor-intensive productions, and that greater investment from the United States and Canada would lead to job creation and increase in wages, thus reducing the need to migrate north for labor and higher wages. This view corresponds to that of economists who see migration as an investment decision, for which the migrant weighs the benefits and costs of moving, whether legally or not (Greenwood, 1985; Hanson and Spilimbergo, 1999). If in the short run the liberalization of exchanges was expected to increase immigration, in the long run, the trade agreement was supposed to reduce the wage differential between Mexico and its northern neighbors, and thus eliminate emigration as a suitable alternative for Mexican workers.

6 There were several obstacles to the implementation of this theory. First of all, the Mexican administration had hoped to emulate the development of other international partnerships, such as the emerging 'Asian Tigers' and the European Union, whose situation did not match that of North America. However, as Fernández-Kelly and Massey noted, the growth of the Asian Tigers relied on strong action taken by the government, and not on 'the weakening of the state [and] laissez faire economics' (2007: 104) which were brought on by NAFTA. As far as Europe was concerned, the Salinas administration was particularly interested in the example of Spain, which had recently witnessed a tremendous growth. Yet the Mexican and U.S. governments neglected to include in the agreement the same precautions that had been taken by the European Union. Indeed, well before the 1992 Maastricht Treaty, important investments had been made into the weaker economies of the Union such as Spain and Portugal, notably to avoid a predictable 'rush' of workers from poorer to richer nations once the borders were open (Uchitelle, 2007). In this perspective, the European Union introduced the concept of "concentric circles" (Domenach, 2001: 57) based on each country's level of closeness to the Union and its economic ties with it. Domenach noted that the establishment of such a system would increase human mobility within this new transnational space. Without these precautions, or the acknowledgment of an old migratory system between Mexico and the United States, the long-term immigration benefits brought by NAFTA were very unlikely.

7 Another assumption of the agreement that proved inaccurate was that emigration from Mexico was more closely related to the Mexican economy than to the U.S. economy, and thus that the stimulation of the Mexican economy would decrease emigration. Yet 
according to a Pew Hispanic Center analysis of immigration to the U.S. between 1992 and 2004, it seems that the Mexican immigration was primarily influenced by changes in the U.S. economy. By looking at the U.S. job expansion and Mexican migration over the same period, Passel and Suro state that 'the annual flow of migrants from Mexico [...] appears to be more closely correlated to macrotrends in the U.S economy than in the Mexican economy' (Passel and Suro, 2005: 11). As evidence of the flawed assumption we can look at the wage differential between Mexico and the United States, which the agreement was supposed to reduce. On the one hand, the agreement did increase the amount of foreign direct investment (FDI) to Mexico, which tripled between 1994 and 2007 (Flores-Macías, 2008). These investments were supposed to support labor-intensive production in Mexico and create more jobs, thus increasing wages in the country. Yet the wage differential between Mexico and its American neighbor 'widened by 7 percent' over the same period of time (2008: 437), which maintained the attractiveness of the U.S. labor market. Others, such as Acevedo and Espenshade (1992), had already pointed out in the early 1990s that the transfer of jobs from the United States to Mexico would not reduce migration because the wage differential would remain large enough, thus encouraging potential migrants to choose international migration to the United States rather than internal migration within Mexico. Therefore, the assumptions that were made at the time underestimated the economic situation in the region, and doomed the immigration expectations of all the parties involved.

\section{The militarization of the border with Mexico}

8 The North American Free Trade Agreement coincided with a tightening and militarization of the border with Mexico. In fact, over the 1990s, state reforms and media coverage contributed to shift the public's perception of the border from a labor issue to a national security issue. States like California made headlines by adopting hardline policies such as Proposition 187 (1994), which prevented undocumented immigrants from using public services, or Proposition 227 (1998) which severely limited bilingual education. The common assumption then was that immigration was increasing sharply and that the United States needed to defend its borders and its culture. Several steps were taken to reassure the public that the government would take care of immigration, and particularly unauthorized immigration. Thus, as Andreas noted, there became an 'apparent paradox of U.S.-Mexico integration [in which] a barricaded border and a borderless economy [were] being created simultaneously' (1999: 593).

9 Several pieces of legislation were adopted during the 1990s that tightened the border and made life more difficult for all migrants, whether lawfully admitted or not. In 1996 Congress adopted three laws related to unauthorized migration. The first was the Antiterrorism and Effective Death Penalty Act, signed in April and intended to deter terrorism. The act suspended certain provisions of Habeas Corpus in cases related to terrorism, and also limited the power of federal judges in such cases. Law enforcement officers were authorized to detain immigrants suspected of terrorism for an indeterminate length of time, and deferred indefinitely the presentation of whatever proof the police had against a particular suspect. In August, Congress passed the Personal Responsibility and Work Opportunity Act, which limited federal assistance to migrants, even those who had been lawfully admitted to the United States. The new law 
stated that migrants could not benefit from federal aid for the first five years of their stay in the United States. Then in September, Congress adopted the Illegal Immigration Reform and Immigrant Responsibility Act. This law allowed the increase in the number of Border Patrol agents by 5,000 before 2001, as well as the construction of a fence on the border south of San Diego (Andreas, 1999).

Several steps were thus taken simultaneously. The Clinton administration reinforced the Border Patrol in an effort to counter Republican criticism that Democrats were too 'soft' on immigration. The budget of the Immigration and Naturalization Service nowadays part of the Department of Homeland Security - was tripled between 1993 and 1999 to reach $\$ 4.2$ billion (Andreas, 1999: 594). The number of agents hired to guard the border between the U.S. and Mexico increased by 83 \% between 1993 and 1997, and new high-tech material such as "infrared night-vision scopes, low-light TV cameras, [and] ground sensors" (ibid, p.595) were given to the agency. The military became more involved on the border as well. Reservists and army engineers were used to build walls and fences along the border. Army equipment such as body sensors, which Andreas notes were originally used in Vietnam, started being used along the line of separation to detect any trespassers. Thus, security agencies whose original goal was to "deter military threats" (ibid, p. 592) were being used to deter unauthorized migration from Mexico and countries in Central America. It seemed that the government of the United States was trying to match the public's change of perception of immigration from a labor issue to a security issue by treating unauthorized migrants as they would any other force threatening their integrity and sovereignty. For example, the United States deployed its national guard on the border with Mexico. Its departure from the region, which had been planned for June of 2011 (Kelly and Wagner, 2011) was recently postponed by the Obama Administration (Dinan, 2011).

11 Thus, while NAFTA was being implemented, the tightening of the border on the U.S. side contrasted sharply with the expectation of increased trade flows. Yet for many reasons, these measures were insufficient to deter an even greater number of migrants from coming to the U. S. in the decade after NAFTA went into force.

\section{The increase in Mexican immigration}

Following the adoption of NAFTA, immigration from Mexico soared throughout the 1990s and early 2000s. At the time, this was understood to be a short-term effect of the implementation of the agreement. In 1990, the Commission for the Study of International Migration and Cooperative Economic Development (CSIMCED) published a report on the likely effects of a free-trade agreement with Mexico. The Commission noted that in the short term the economic development of the Mexican economy would lead to an increase in immigration. However, those who predicted a long-term decrease in immigration failed to anticipate the importance of the U.S. pull factors for unemployed or displaced Mexican workers. Mexican migration is indeed driven by both pull factors from the U.S. labor market (better wages, living standard, the ability to send money home), and push factors in Mexico (economic crisis, worker displacement, violence). In this case, it was assumed that by dealing with the push factors, immigration could be reduced, which proved not to be the case. However, it is true that a short-term increase in migration was expected by those who signed the agreement. But several elements contributed to exacerbate and prolong the effects of this increase. 
13 First of all, Mexico experienced a crisis at the end of 1994 and the beginning of 1995 that increased the number of potential migrants. This crisis was both financial and political. During the 1994 presidential campaign, the assassination of Luis Donaldo Colosio, a candidate from the ruling PRI, sent a negative message to potential investors who repatriated their capital. Indeed, investors feared a change in governmental decisions away from the policies of the PRI, which had been behind the neoliberal orientation of Mexico. After the peso was devalued by $120 \%$, inflation surged from 7 to $52 \%$ in 1995 and investors lost confidence in the country. According to Gustavo FloresMacías, "that year Mexico's economy shrank by 6.2 percent in real terms" (2008: 437). This series of events contributed to an increase in the number of people attempting to cross the border into the United States. In the early and mid-1990s, the average level of immigration to the United States was about 1 million people a year, but from 1995 to 1997 that number increased to 1.2 million per year (Passel and Suro, 2005). This predictable short-term migration increase did not level until off after a few years. Immigration to the U.S. peaked between 1999 and 2000 to reach "at least 1.5 million per year [...] which may understate the inflows of immigrants, since about 1.8 million arrived in 1999 according to data from Census 2000" (ibid, 3). The share of Mexicans in this cohort was stable at about a third of the total inflow, with roughly 500,000 Mexican migrants crossing the border during the peak years of 1999 and 2000. Thus, the first years of the implementation of NAFTA actually coincided with a sharp increase in Mexican immigration to the United States.

14 Another factor to take into account is the attractiveness of the U.S. labor market for displaced Mexican workers. Before NAFTA was implemented, Mexico's collective farms were privatized and agricultural subsidies were largely eliminated, resulting in an increase in the number of peasants seeking opportunities north of the border. Meanwhile, the U.S. labor market expanded in the 1990s, especially in the peak migration years of 1999 and 2000. After the 1991 recession, the labor market increased by 1.59 million in 1993, and then by 1.85 million in 1998 (Passel and Suro, 2005: 10). This labor market was particularly welcoming to cheap Mexican labor. Passel and Suro note that in 2000, "both the U.S. expansion and the growth of Mexican migration reached a peak" (ibid). There is therefore a very strong interdependence between the labor market in the United States and Mexican migrant labor. In fact, despite the political talk of controlling unauthorized immigration, Congress and various administrations have failed to actually adopt a law that would effectively curb the employment of undocumented workers. In 1996, only 2 percent of the budget of the INS was dedicated to investigating employers and sanctioning those who employed undocumented migrants (Andreas, 1999). According to Peter Andreas, the United States "ranks among the lowest [industrialized countries] in terms of sanctions against employers of illegal immigrants" (ibid, p. 603). There seems to be a contradiction between the displayed intent of the U.S. to control undocumented immigration on the one hand and, on the other, the economic interest of the nation in letting in cheap Mexican labor to support the economy.

Emigration from south of the border soared in the 1990s, while the U.S. administration attempted to seal its border against trespassers. This has paradoxically led to an increase in the number of undocumented people living in the United States, as the perspective of getting caught during seasonal migrations has convinced some migrants that it was safer to simply stay in the country for good. This trend has had serious 
consequences on immigration patterns as well as on the lives of new receiving states in the United States.

\section{The Growth of the Undocumented Population in the United States.}

\section{A riskier, deadlier border}

As we have seen, the tightening of the border with Mexico has not stopped people from immigrating to the United States. But it has in fact had one major consequence on their immigration choices: more and more unauthorized migrants are choosing to stay in the United States to avoid getting caught at the border (Cornelius, 2004). Until the mid-1990s, it was common for seasonal workers to cross the border when their labor was needed, and to go back to Mexico once the season was over (Espenshade, 1994). Lindstrom (1996) provides a thorough review of the literature on the "temporary nature of current and past migration to the United States" (1996: 357). The number of apprehensions at the border reflects this trend, as shown in a Pew Hispanic Report from 2007: "The highest numbers of apprehensions are recorded from February to March as migrants move north for the construction and harvesting seasons" (Pew Hispanic Center, 2007: 12). This also shows once again the strong relationship between Mexican migration and the needs of the U.S. labor market. Yet, because of the strong stance taken by the American government and the changes made along the border, these seasonal crossings have become riskier. This effect had already been felt after the implementation of the Immigration Reform and Control Act of 1986, which allowed for the granting of temporary status to undocumented workers who had arrived in the United States before January $1^{\text {st }}, 1982$, while introducing tougher sanctions on those who employed undocumented workers. However, the law did not translate into actual enforcement and oversight of workers' status. In fact, Roger Daniels noted on the subject that this law "may have had the paradoxical effect of keeping more Mexican illegals in the United States than it kept out, as many [...] were now afraid that they would not be able to return" (2002: 397). The new sanctions introduced in the mid-1990s had similar consequences, which helped sustain the development of a new regional system.

There are two main risks encountered by those who decide to cross the border into the United States illegally. First of all, as we have seen, the surge in technology and manpower along the border has led to an increase in the number of apprehensions. The Border Patrol reported "a high of 1.8 million" caught in 2000, with the vast majority of them - over $85 \%$ - Mexican nationals ( $\mathrm{Wu}, 2006: 1)$. Of course, part of these 1.8 million is actually made up of single individuals being arrested several times. A report from Homeland Security showed that, as the U.S. economy declined, so did the number of apprehensions on the border (Rytina and Simanski, 2009). They also stated that a possible reason for the decrease in apprehensions was the "enhanced border enforcement efforts" (ibid, p.1). Another consequence of the tightening of the border is the increase in deaths in the region due to the more dangerous routes taken by unauthorized migrants. Because regular ports of entry such as the south of San Diego have been sealed off and walls have been built, the flow of migrants has moved eastward to areas that are more difficult to cross on foot, such as the Sonora Desert in 
Arizona. A recent report from the ACLU estimated that the number of deaths on the border since the beginning of "Operation Gatekeeper" ranged between 3,861 and 5,607 (Jimenez, 2009).

18 All these factors have contributed to the growth of the undocumented population in the United States. While the number of legal permanent residents in the country actually decreased in the 1990s, the number of unauthorized migrants grew sharply. According to the Pew Hispanic Center, undocumented migrants "represented fewer than four in ten new immigrants before the peak [of 1999-2000] and almost five in ten afterwards" (2005: 5). This growth of the undocumented population did not slow down for a few years. Passel noted in 2005 that the annual average growth of this group between 2000 and 2004 had been "about 485,000 per year" (2005: 2). The share of Mexican nationals in the undocumented population remained stable over the 1990s and early 2000s, at about $60 \%$ (compared to a third only for all immigrants). Thus, at the beginning of the implementation of NAFTA, most of the immigration from Mexico was unauthorized and largely contributed to the growth of the undocumented population living in the United States. However, the number of undocumented immigrants in the United States has decreased over the last few years, from an estimated 12 million people in March 2007 to 11.1 million in March 2009 (Passel and Cohn, 2010), even if the size of the Mexican undocumented population has remained fairly stable at 7 million individuals since 2007.

\section{The predominance of Mexicans among the undocumented}

As noted before, Mexicans represent over half of the undocumented population residing in the United States. This fact shows that the assumed benefits of NAFTA were unable to counter a trend that started decades ago and which has led to a surge of the share of Mexican unauthorized immigration compared to the share of legal migration. As Nicholas de Genova puts it:

Mexican migration to the U.S. is distinguished by a seeming paradox that is seldom examined: while no other country has supplied nearly as many migrants to the U.S. as Mexico has since 1965, virtually all major changes in U.S. immigration law during this period have created ever more severe restrictions on the conditions of "legal" migration from Mexico. (2006: 61)

Mexican migrants were in fact an essential part of the development of the Southwest of the United States, and before World War II they were encouraged to migrate north to work in the agricultural sector. De Genova notes in particular that the introduction of numerical quotas in 1924 left out the entire Western Hemisphere, and Mexico with it. The first form of control came during the Great Depression, when about half a million Mexican migrants were "repatriated" to Mexico. During the war, both governments initiated the Bracero Program, providing cheap labor for U.S. agriculture and railroad construction. Yet, the program not only encouraged the trend of Mexican labor crossing the border, it also enabled even more undocumented migrants to come to the United States "through the development of a migration infrastructure and through employers' encouragement of braceros to overstay the limited tenure of their contracts" (ibid, 66). The official end of the program did not decrease the need for this type of labor, and immigration continued outside of any form of official program.

21 The 1965 immigration law established for the first time a numerical quota on legal migration from the Western Hemisphere, and later amendments only diminished the 
number of people allowed to emigrate each year from Latin America. This was particularly detrimental to Mexicans, who had been the most numerous group immigrating to the U.S., but who were given the same number of "legal entries" as other countries, slightly under 20,000 a year. De Genova thus shows that even if 151,000 Mexicans were already being deported each year at the time the law was adopted, the law only authorized 120,000 legal entries from the entire Western Hemisphere (ibid, 71). In 1976, a revision of the law gave each country of the hemisphere 20,000 legal migrants, while that same year the number of apprehensions of Mexicans on the border reached 781,000. Thus, the gap between the reality of Mexican migration and the U.S. legislation has been consistently unfavorable towards Mexican legal migration. Most of the recent changes in U.S. immigration policies seem to have created a scenario where Mexican migrants have no choice but to migrate illegally. Relocating legally to the U.S. from Mexico can take years, but it can also never happen if admission is simply refused. Espenshade (1994) points out that the first Mexicans granted residency under the third preference category in March 1994 had had their applications approved in 1985. The author explains that the rewards of immigrating illegally in terms of job opportunities and connections with family often outweigh the perceived benefits of waiting years for a visa. The combination of a strong migrant network in place for decades and of job opportunities, associated with the near-impossibility of immigrating legally to the United States, have contributed to the growth of the undocumented population from Mexico.

Mexicans represent today the largest number of unauthorized and legal migrants in the United States, with each group numbering respectively 7 and 5.7 million people (Pew Hispanic Center, 2009). This report notes that Mexicans represent $32 \%$ of all foreignborn living in the country. Even if this figure is used by many politicians to show the lack of federal control over immigration, the authors of the report remind us that this kind of concentration is indeed very high, but not unheard of. In fact, Irish immigrants "represented a third or more of the immigrant population from 1850 to 1870 [...] and Germans were $26 \%$ to $30 \%$ of the foreign-born population from 1850 to 1900" (2009: 2). Thus the high concentration of Mexicans in the United States, as well as the unauthorized nature of their migration pattern, could be seen as a repetition of a wellknown trend in a country so often defined as a "nation of immigrants." What is different today is that the United States is no longer transformed by a westward expansion but by a new immigration driven by the south that redefines the social and economic relationships in the entire region.

\section{New immigration states}

Since the mid-1990s, the share of unauthorized immigrants among Mexicans has increased compared to legal arrivals. These recent, undocumented migrants vary greatly from former immigrants in several aspects that all impact the region where they settle. First, Mexican migrants in general tend to be younger than other immigrants or than the U.S. population. Secondly, according to the Pew Hispanic Center, they "have lower levels of education, lower incomes, larger households and higher poverty rates than other groups" (2009: 3). These characteristics are greatly magnified when one looks more specifically at undocumented immigrants. This particular group is also younger, with less than $10 \%$ of them over the age of 40 , and one in six being under the age of 18 (Passel, 2005: 1). Unauthorized migrants are also 
much more likely to have even less education than other migrants, and to speak English less than well.

All these factors affect the states where undocumented immigrants settle. Among these are traditional immigration states such as California or New York, which have long had a large foreign-born population, and where these immigrants benefit from strong networks that provide assistance. But over the last decade, new immigration states have emerged that are not familiar with immigrant populations and where the relationship between migrants and state governments is much more confrontational. The most recent report from the 2010 Census indicates that the Hispanic population grew most significantly in the South and the West of the United States between 2000 and 2010 (Ennis et al., 2011). The Hispanic population in the South and the Midwest grew respectively by 57 percent and 49 percent (ibid, p. 4). These new states include Arizona, Nevada, Utah, North and South Carolina, Georgia, Arkansas, Louisiana, oklahoma and Tennessee. The new immigration pattern for undocumented migrants has led to a rapid diffusion of this population over the South and Southeast of the United States, with less concentration in traditional immigration states. Passel noted that "by 2004, an estimated 3.9 million undocumented migrants lived outside of those traditional settlement states," compared to only 400,000 in 1990 (2005: 3). In these new immigration states, the undocumented population makes up to $40 \%$ of the total foreign-born population.

As we have seen, these new immigration states are not as used to large foreign-born populations as traditional settlement states, and most of the time they do not provide specific services like translators or bilingual education at school. They are, however, more dynamic economically and thus attract a large new population that is not limited to Hispanic migrants, but that also includes black and white nationals. The Hispanic population in these states has experienced a tremendous growth between 2000 and 2010: that of North Carolina has increased by 111 percent, that of South Carolina by 147 percent, that of Alabama by 144 percent, and that of Arkansas by 114 percent (Census Data 2010). This growth has had a serious impact on the infrastructure of the new receiving states, and particularly on public services. This new pressure has led a significant portion of the population of these states to support legislators who advocate the restriction of access to services such as health care, housing and education. This had been the case in the past in California with the 1994 "Save Our State" Initiative, and more recently in new immigration states such as Arizona, Georgia, and North Carolina.

Examples of this type of reaction targeting more specifically undocumented immigrants are given by Cortez (2008), who cites initiatives taken by local governments in Pennsylvania and New Jersey in 2006. In July of that year, the town of Hazleton, Pennsylvania, passed the Illegal Immigration Relief Act Ordinance, prohibiting business from hiring unauthorized immigrants and fining landlords 1,000 dollars for renting to them (ibid, p. 58). The ban was eventually judged unconstitutional in federal court. Another example made headlines when, in the spring of 2010, Arizona passed Senate Bill 1070, which states that "A law enforcement officer, without a warrant, may arrest a person if the officer has probable cause to believe that the person has committed any public offense that makes the person removable from the United States." The text of the law failed to specify what could constitute such "probable cause." The number of state laws related to immigration issues has exploded over the last few years. A recent report from the National Conference of State Legislatures (NCSL) noted that whereas in 
2005 there had been 300 bills introduced on this topic and 38 laws enacted, in 2010 there were more than 1,400 bills introduced and 208 laws enacted, with an additional 138 resolutions (Johnston and Morse, 2011). The multiplication of state activity regarding immigrants and their rights shows that these states are faced with a new situation for which they were unprepared.

New immigration states often seem to respond negatively to an increase in their foreign-born population because of the impact of this population on an infrastructure that is not ready to accommodate them. This response often translates into state laws affecting the lives of immigrants, while older immigration states tend do so through local initiatives, as was the case in Pennsylvania or more recently in California. Thus, we can see the development of a new regional system driven by a region stretching from the west coast of the U.S. to the mountain states and the old south where an increase in the immigrant population, and particularly in its undocumented share originating from Mexico, has led legislatures to take action. These new immigration states reinforce the existence of the entire system encompassing Mexico and the U.S., where people move north in search of work and send money south to their countries of origin.

\section{A Parallel 'Integrated Region’ Outside NAFTA}

\section{The role of remittances}

Over the last fifteen years, there has been an important increase in the amount of money transferred from the United States to Mexico and other countries in the form of remittances. In 2003, a joint report from the Pew Hispanic Center and the Multilateral Investment Fund stated that "the total remittance flow from the United States to Latin America and the Caribbean [came] close to $\$ 30$ billion" (Suro, 2003: 3). The amount sent to Mexico, El Salvador, Guatemala, Honduras and Nicaragua had totaled 10.2 billion dollars in 2000, and was expected to reach 14.2 billion in 2002 and 18 billion in 2005. The figure for Mexico alone was $\$ 23$ billion in 2006 (Waldinger, 2007: 9), and $\$ 26$ billion in 2007. The flow of remittances slowed down only in 2009, due to the financial crisis. However, for 2009, the amount of remittances sent to Mexico was over $\$ 21$ billion (MIF, 2009), by far the largest amount received in Latin America. Remittance senders are mostly recent immigrants and thus their characteristics match those of unauthorized migrants from Mexico: they usually have little education, earn low incomes and do not speak English well, which hinders their knowledge of the U.S. banking system. The vast majority of remittance senders originate from poor workers. Receivers, on the contrary, are a varied group, especially in Mexico. $18 \%$ of the adult population receives remittances, which are sent to "all sectors of Mexican society and to virtually every region" (Suro, 2003: 4). Most other receiving countries in Central America show a concentration of remittance receivers in the poorer categories of the population.

Remittances play a part in this parallel integration of the region, not only because they represent a transfer of money from the north to the south, but because they encourage immigration among those who receive them. According to Gustavo Flores-Macías, remittances strengthen the bonds between sending and receiving communities, and thus "perpetuate the social expectation [...] of migrating north in order to achieve a better living standard" (2008: 438). The ability to provide assistance to people who have 
stayed in the country of origin also plays a part in this pattern. Thus remittances are not just a consequence of immigration, but are also a motivation for immigration. The Pew Hispanic Center report takes the example of Ecuador, where remittances are used primarily to respond to a crisis. According to the authors, "the ability to establish a monetary flow from abroad quickly and of sufficient size to ensure a family's economic survival is now a ready means of dealing with economic, political and environmental crises" (Suro, 2003: 13). In the case of Mexico, where remittances are sent to all socioeconomic groups in society, remittance receivers are more likely than others to consider immigration in their future. Therefore, remittances are an essential part of the 'shadow' integration of the region: they not only provide the flow of money from the north to the south, but they also encourage and finance the movement of people from the south to the north.

The case of Mexico and the implications of remittances for immigration control are of particular importance. As we have seen before, most official agreements between the United States and Mexico, including NAFTA, aim to reduce immigration on the long term. In the case of NAFTA, this indirect goal was supposed to be achieved through an increase in wages, and therefore targeted those from the lower socio-economic levels of Mexican society. Yet as we have also seen, remittances are sent to a larger segment of the Mexican population than in other countries, and have little to do with income and educational attainment. Therefore any immigration plan that solely aims at improving the lives of the poorest in the nation would only have a limited impact. According to the Pew Hispanic Center, "programs that aim at diminishing migration pressures [...] will have to be as broad-based as the remittance flow" (Suro, 2003: 9). The goals set up by NAFTA therefore appear too limited to truly slow down the immigration flow originating from Mexico. The characteristics of remittance senders and receivers in this country are too close to those of the general population for the limited impact of a trade agreement to have any lasting effect on immigration. Remittances do help the receiving countries, especially when they are used to develop personal businesses and other investment, but they do not prevent immigration.

\section{The darker side of the system}

31 In some ways, these new flows of people and money have benefitted less the administrations that tried to organize the economic integration of the region through NAFTA than 'shadow' organizations that have developed around unauthorized immigration and the exploitation of migrants and their families. These groups include not only the financial institutions that transfer remittances, but also human traffickers, smugglers, coyotes, organized crime, drug cartels and those specializing in the production of fraudulent documents, all of whom have flourished since the tightening of the border between the U.S. and Mexico. Because the border is now so difficult to cross, it has become more common for potential unauthorized immigrants to use the services of coyotes. They, in turn, have increased their fees due to the conjunction of a higher demand and of a higher risk. Peter Andreas noted in 1999 that transportation fees had doubled from $\$ 250$ to at least $\$ 500$ (1999: 599). The specialization of law enforcement technologies has led smugglers to mirror the actions of the government. Andreas writes that higher fees have enriched "increasingly sophisticated and wellorganized binational smuggling groups" (1999: 600). Thus, a parallel economy has developed along the border with the sole purpose of providing people with access to 
the United States. This economy includes services such as transportation, border crossing, and more specific products such as fraudulent documents. Law enforcement agencies have not been able to prevent the rapid outflow of people from Mexico, and seem to have actually promoted the development of a 'shadow' economy devoted to unauthorized immigration.

In addition, the relationship between the United States and Mexico has suffered from the ongoing violence brought on by drug cartels throughout Mexico as well as by the harsh response to these groups by the government. Once again, this aspect of the system involves flows of money from the United States to Mexico, to which we can add the transportation and sale of weapons. A 2000 report prepared for the office of National Drug Control Policy indicated that Americans spent $\$ 65$ billion annually on illicit drugs such as cocaine, heroin, and marijuana, most of which are, according to Tim Padgett, "either produced in Mexico or transit trough it" (2011: 19). In addition to drugs, law enforcement agencies in the United States have recently made headlines in the revelation of "Operation Fast and Furious" (Serrano, 2011), through which the Bureau of Alcohol, Tobacco, Firearms and Explosives (ATF) allowed for the sale of guns in the hope that they would later be traced to drug cartel leaders. Unfortunately, some of the guns were lost and only recovered at crime scenes in Mexico as well as in the United States. This darker aspect of the transnational space which is emerging between Mexico and the United States, through the actions of both migrants and governments, threatens American security and economic interests (National Drug Intelligence Center, 2011), and is in direct contradiction with the institutional security partnership established between the two countries. Indeed, in 2005 the U.S. and Mexico, along with Canada, signed the Security and Prosperity Partnership of North America, which not only promoted economic cooperation between the three countries, but also intended to protect them against common risks they faced. These risks were not limited to terrorist threats and natural disasters, but also included dangers faced by transportation and energy infrastructures on the entire continent. The increase in violence and criminal activities around the border with Mexico today shows the limits of this partnership.

\section{A new 'integrated region'}

Through the intensification of two types of flows, people and money, a parallel form of regionalism has emerged, encompassing Mexico and the South and Midwest of the United States. This system is likely to stay in place and flourish since both immigration and remittances have accelerated in the last fifteen years. Moreover, as immigration provides for more remittances, the latter encourages people to stay longer in their new area of settlement. In countries such as El Salvador, Guatemala or Honduras, more than half the adult population has a relative abroad that has been sending them money for over five years (Suro, 2003: 15). Thus, researchers from the Pew Hispanic Center talk about the "staying power" of remittances, as families and nations depend on this influx of money from abroad (ibid.: 15).

As people move north and stay longer, new forms of communications are developed to stay in touch with their country of origin. Remittances are of course one of these forms of contact, but so are emails, phone calls, and actual travel (Suro, 2005; Waldinger, 2007). Yet there seems to be an oppositional relationship between travel and remittances. On the one hand, most of the money transferred abroad is sent by recent 
immigrants, and the share of immigrants sending money home decreases with their length of stay in the United States. On the other hand, recent migrants "account for most of the immigrants who have never traveled back or have not done so recently" (Waldinger, 2007: 5). The key element in this opposition is citizenship. Immigrants who have been in the United States longer are more likely to have naturalized as American citizens, which can facilitate their travel. On the contrary, those who arrived within the last ten years are more likely to have come illegally. This is especially true of Mexican immigrants, about half of whom are currently undocumented. Thus, the acquisition of citizenship appears to be important in order to maintain direct contact with home countries, but it does not prevent people from sending money abroad. The regional system that develops is therefore not one that requires a common identity, but that is mostly based on economic and demographic characteristics.

This shadow regionalism is acknowledged by the main actors on both sides of the border. In the United States, more and more efforts are made to capture the evergrowing remittance market. Banks are trying to reach out to millions of potential customers who are not familiar with the U.S. system. Some of them have started accepting 'matriculas'- Mexican identity cards delivered by Mexican consulates and showing the individual's U.S. address - as the necessary paperwork to open a bank account. This is particularly important for unauthorized immigrants who would otherwise be precluded from opening an account from where to send money abroad. Due to efforts from the Mexican government to improve its consular services in the U.S., matriculas were in 2002 accepted by 66 banks, hundreds of police departments, and could be used in 13 states to acquire a drivers' license (Suro et al., 2002: 15). The Pew Hispanic Center also noted the efforts of Latino groups to provide financial literacy training to recent immigrants, thus improving both their knowledge of American society and the standard of living of their relatives abroad. The current competition to enter this new market and control it shows that the remittance market, and the 'shadow' regionalism from which it has emerged, is widely accepted as a fact of American economic life. An example of this is the 2009 ad campaign run by Walmart to promote its Money Center, where services like check cashing and international transfers are now provided. The ads prominently featured Latino individuals and families. The remittance market and its customers have now become a fixture of the U.S. economy, one that is likely to strengthen the bond between the United States and Mexico in the future through deeper economic and social interdependence across the border.

\section{Conclusion}

NAFTA has brought some economic gains to the United States and Mexico -admittedly unevenly distributed - even though their economic partnership now ranks behind the relationship between the United States and China. The liberalization of trade between the two countries has, however, helped the acceleration of the amount of remittances sent to Mexico, which only started slowing down in 2008. Nevertheless, the 25 billion dollars sent that year represented the second-largest source of income for that country. The economic gains of receiving countries from remittances is undeniable, but some also look at their role in encouraging unauthorized immigration as a benefit for the United States too. The slow evolution of federal immigration law concerning the 
employment of undocumented workers has done little to curb the American labor market's appetite for this type of labor, and we echo Douglas Massey in viewing both the economic and the immigration policies of the United States as two policies "moving in a diametrically opposed direction" (Massey, 2003: 2). In this perspective, the development of a region where remittances sent from the United States by recent immigrants encourage and finance the arrival of more Mexican labor can be seen as a parallel form of integration, not explicitly planned by NAFTA, but in other ways beneficial to both partner countries.

\section{BIBLIOGRAPHY}

Acevedo, Dolores and Thomas Espenshade, "Implications of a North American Free Trade Agreement for Mexican Migration into the United States" Population and Development Review, Vol. 18, No. 4, 1992, pp. 729-744.

Andreas, Peter, “The Escalation of U.S. Immigration Control in the Post-NAFTA Era." Political Science Quarterly, Vol. 113, No. 4, 1999, pp. 591-615.

Arizona State Legislature, Senate Bill 1070. Phoenix, Arizona, 2010.

Commission for the Study of International Migration and Cooperative Economic Development, Report: hearing before the Committee on Foreign Affairs, House of Representatives, One Hundred First Congress, second session, 1990.

Cornelius, Wayne, "Evaluating Enhanced US Border Enforcement." Migration Policy Institute. Washington, D.C. , 2004. http://www.migrationinformation.org/feature/display.cfm?ID=223. Accessed February 15, 2010.

Cortez, Nathan, "The Local Dilemma: Preemption and the Role of Federal Standards in State and Local Immigration Laws" Southern Methodist University Law Review, Vol. 61, 2008, pp. 47-66.

Daniels, Roger, Coming to America, a History of Immigration and Ethnicity in American Life. Perennial (Second Edition), New York, NY, 2002.

De Genova, Nicholas, “The Legal Production of Mexican/Migrant “Illegality.” In Oboler, Suzanne, 2006, Latinos and Citizenship, The Dilemma of Belonging. Palgrave Macmillan, New York, NY, 2006.

Dinan, Stephen, "Obama Extends National Guard Deployment on Southern Border" The Washington Times, June $17^{\text {th }}, 2011$.

Domenach, Hervé, “Les Migrations Internationales” in Lery, Alain and Patrice Vimard (eds), Population et Développement : les principaux enjeux cinq ans après la Conférence du Caire. Centre Français sur la Population et le Développement, No. 12, 2001, pp. 51-58.

Ennis, Sharon, Merarys Ríos-Vargas and Nora Albert, “The Hispanic Population: 2010" 2010 Census Brief, U.S. Census Bureau, 2011. http://www.census.gov/prod/cen2010/briefs/c2010br-04.pdf Accessed July 1st, 2011.

Espenshade, Thomas, "Does the Threat of Border Apprehension Deter Undocumented US Immigration?" Population and Development Review, Vol. 20, No. 4, 1994, pp. 871-892. 
Faist, Thomas, "Migrants as Transnational Development Agents: An Inquiry into the Newest Round of the Migration-Development Nexus." Population, Space and Place, Vol. 14, 2008, pp. 21-42. Fernández-Kelly, Patricia and Douglas S. Massey, "Borders for Whom? The Role of NAFTA in Mexico-U.S. Migration." The ANNALS of the American Academy of Political and Social Science. March 2007. No. 610 , pp. $98-118$.

Flores-Macías, Gustavo, "NAFTA's Unfulfilled Immigration Expectations.” Peace Review, Vol. 20, No. 4, 2008, pp. 435-441.

Greenwood, Michael J., “Human Migration: Theory, Models, and Empirical Studies” Journal of Regional Science, Vol. 25, No. 4, 1985, pp. 521-545.

Hanson, Gordon and Antonio Spilimbergo, "Illegal Immigration, Border Enforcement, and Relative Wages: Evidence from Apprehensions at the U.S.-Mexico Border." The American Economic Review, Vol. 89, No. 5, 1999, pp. 1337-1357.

Jimenez, Maria, 2009, "Humanitarian Crisis: Migrant Deaths at the U.S.-Mexico Border" ACLU of San Diego and Imperial Counties, Mexico's National Commission of Human Rights. http:// www.aclu.org/files/pdfs/immigrants/humanitariancrisisreport.pdf Accessed July 1st, 2011.

Johnston, Gillian and Ann Morse, “2010 Immigration-Related Laws and Resolutions in the States" National Conference of State Legislature, Immigrant Policy Project, 2011.

Kapur, D., "Remittances: The New Development Mantra?" G-24 Discussion Paper Series, No. 29. Washington, D.C.: The World Bank, 2004.

Kelly, Erin and Dennis Wagner, "National Guard troops to leave Mexico border in June" USA Today, March $16^{\text {th }}, 2011$.

Levitt, Peggy and Nadya Jaworsky, "Transnational Migration Studies: Past Developments and Future Trends." Annual Review of Sociology, Vol. 33, 2007, pp. 129-156.

Lindstrom, David, "Economic Opportunity in Mexico and Return Migration from the United States” Demography, Vol. 33, No. 3, 1996, pp. 357-374.

Massey, Douglas, Beyond Smoke and Mirrors: Mexican Immigration in an Era of Economic Integration. Russell Sage Foundation Publications, 2003.

Multilateral Investment Fund, Remittances to Latin America and the Caribbean in 2009 - The Impact of the Global Financial Crisis. Inter-American Development Bank, New York, 2009.

Padgett, Tim, “Day of the Dead. The Drug War is Mexico's Strategy.” Time, July $11^{\text {th }}, 2011$.

Passel, Jeffrey, "Estimates of the Size and Characteristics of the Undocumented Population." Pew Hispanic Center, Washington, D.C., 2005. http://pewhispanic.org/files/reports/44.pdf. Accessed November 8, 2007.

Passel, Jeffrey and Roberto Suro, “Rise, Peak, and Decline: Trends in U.S. Immigration 1992-2004." Pew Hispanic Center, Washington, D.C., 2005. http://pewhispanic.org/files/reports/53.pdf. Accessed December 15, 2009.

Passel, Jeffrey and D'Vera Cohn, “U.S. Unauthorized Immigration Flows Are Down Sharply Since Mid-Decade.” Pew Hispanic Center, Washington, D.C., 2010. http://pewhispanic.org/files/reports/ 126.pdf Accessed July 1st, 2011.

Pew Hispanic Center, "Indicators of Recent Migration Flows from Mexico. Fact Sheet." Washington, D.C., 2007. http://pewhispanic.org/files/factsheets/33.pdf. Accessed December 15, 2009. 
Pew Hispanic Center, "Mexican Immigrants in the United States, 2008." Fact Sheet, Washington, D.C., 2009. http://pewhispanic.org/files/factsheets/47.pdf. Accessed April 20, 2009.

Rhodes, William, Mary Layne, Patrick Johnston, and Lynne Hozik, “What America'sUsers Spend on Illegal Drugs, 1988-1998” Office of National Drug Control Policy, Washington, D.C., 2000. https://www.ncjrs.gov/ondcppubs/publications/pdf/spending_drugs_1988_1998.pdf Accessed July 2nd, 2011.

Rytina, Nancy and John Simanski, “Apprehensions by the U.S. Border Patrol: 2005-2008." Department of Homeland Security Office of Immigration Statistics, Washington, D.C., 2009. http://www.dhs.gov/xlibrary/assets/statistics/publications/ ois_apprehensions_fs_2005-2008.pdf. Accessed January 20, 2010.

Serrano, Richard, "More U.S. Agencies Implicated in Mexico Gun-Trafficking Probe" Los Angeles Times, July $7^{\text {th }}, 2011$.

Smith, Robert C., Mexican New York: Transnational Lives of New Immigrants. Berkeley: University of California Pres, 2006s.

Suro, Roberto and Sergio Bendixen, B. Lindsay Lowel, Dulce C. Benavides, "Billions in Motion: Latino Immigrants, Remittances and Banking." Pew Hispanic Center and the Multilateral Investment Fund, Washington, D.C. , 2002. http://idbdocs.iadb.org/wsdocs/getdocument.aspx? docnum=548657. Accessed December 15, 2009.

Suro, Roberto, "Remittance Senders and Receivers: Tracking the Transnational Channels." Pew Hispanic Center and the Multilateral Investment Fund, Washington, D.C., 2003. http:// idbdocs.iadb.org/wsdocs/getdocument.aspx?docnum=548518. Accessed December 15, 2009.

Suro, Roberto, "Survey of Mexican Migrants (Part Two). Attitudes about Voting in Mexican Elections and Ties to Mexico." Pew Hispanic Center, Washington, D.C., 2005. http:// pewhispanic.org/files/reports/42.pdf. Accessed February 16, 2009.

Uchitelle, Louie, “Nafta Should Have Stopped Illegal Immigration, Right?" The New York Times, February $18^{\text {th }}, 2007$. New York, NY, 2007.

United States Department of Justice, "The Economic Impact of Illicit Drug Use on American Society” National Drug Intelligence Center, Washington, D.C., 2011.

Vertovec, Steven, "Migrant Transnationalism and Modes of Transformation." International Migration Review, Vol. 38, No. 3, Conceptual and Methodological Developments in the Study of International Migration, 2004, pp. 970-1001.

Waldinger, Roger, "Between Here and There: How Attached Are Latino Immigrants to Their Native Country?" Pew Hispanic Center, Washngton, D.C., 2007. http://pewhispanic.org/files/ reports/80.pdf. Accessed January 5, 2010;

Wu, Amy, "Border Apprehensions: 2005." Department of Homeland Security Fact Sheet from the Office of Immigration Statistics. Washington, D.C., 2006. http://www.dhs.gov/xlibrary/assets/ statistics/publications/ois_apprehensions_fs_2004.pdf. Accessed January 20, 2010.

\section{ABSTRACTS}

The reduction of immigration was never an official objective of the North American Free Trade Agreement. Yet, it was generally supposed to be one of its long-term consequences. Fifteen years later, Mexican immigration to the United States has in fact increased. The agreement has failed to reduce the attractiveness of the U.S. labor market for Mexican workers and to provide 
sustainable alternatives to immigration. Over the same period of time, American politicians and the American media have consistently embraced a narrative in which immigration control has become a matter of national security. A paradox has emerged from these two conflicting trends. While the measures taken by the federal government have failed to prevent unauthorized migrants from entering the country, they have also encouraged them to stay longer in the U.S. by making border-crossings too risky. The 1990s therefore witnessed a significant growth of the undocumented population of the United States.

This paper analyzes the emergence of a "shadow" regional system between Mexico and the U.S., driven by immigrants themselves, as well as those who profit from undocumented immigration, rather than by institutional actors. This shadow integration is the product of two types of flows: people moving north of the border and, increasingly, remittances moving south. Remittances in turn reinforce immigration trends since they perpetuate the expectations of immigrants. This article examines the development of this parallel form of integration that has taken place at the same time as the implementation of the trade agreement, beyond the control of the Mexican and American governments.

La réduction des flux d'immigration n'a jamais été un objectif officiel de l'Accord de Libre Échange Nord Américain. Cependant, elle a souvent été envisagée comme une conséquence à long terme de sa mise en place. Quinze ans plus tard, l'immigration vers les États-Unis en provenance du Mexique s'est en réalité accélérée. L'accord n'a pas pu réduire l'attractivité du marché du travail américain pour les travailleurs mexicains et produire une alternative durable à l'immigration. Au cours de la même période, les hommes politiques et les médias américains ont adopté l'idée selon laquelle le contrôle de l'immigration serait devenu un problème de sécurité nationale. Un paradoxe a émergé de ces deux tendances conflictuelles. Alors que les mesures prises par le gouvernement fédéral n'ont pu prévenir l'afflux d'immigrés sans papiers, elles ont en revanche accru la durée de séjour de ces derniers en accroissant les risques liés à la traversée de la frontière. Dès lors, les années 1990 ont connu une augmentation significative de la population sans papiers des États-Unis.

Cet article analyse l'émergence d'un système régional d'intégration entre le Mexique et les ÉtatsUnis, impulsé par les immigrés eux-mêmes, ainsi que par ceux qui profitent de l'immigration irrégulière, plutôt que par les acteurs institutionnels. Cette intégration informelle est le produit de deux types de mouvement : celui des migrants vers le nord de la frontière et, de plus en plus, celui de leurs transferts de fonds vers le sud. Ces transferts alimentent à leur tour les flux d'immigration, puisqu'ils perpétuent les attentes des immigrés. Cet article examine le développement de cette forme parallèle d'intégration qui s'est déroulé au même moment que la mise en place de l'accord de libre-échange, au-delà du contrôle des gouvernements mexicain et américain.

La reducción de los flujos de inmigración nunca fue un objetivo oficial del Tratado de Libre Comercio de América del Norte. Sin embargo, ha sido considerada, muchas veces, como una consecuencia a largo plazo de la ejecución de dicho tratado. En realidad, quince años después, la inmigración desde México hacia los Estados Unidos ha aumentado. El tratado no ha podido reducir el poder atractivo del mercado laboral norte americano en los trabajadores mejicanos ni proponer tampoco una alternativa sostenible a la inmigración. Durante el mismo periodo, los hombres políticos y los medios de comunicación norteamericanos adoptaron la idea según la cual la inmigración se hubiera convertido en un problema de seguridad nacional. Una paradoja surgió de estas dos tendencias conflictuales. No sólo las medidas que tomó el gobierno federal no pudieron prevenir la afluencia de inmigrantes indocumentados, sino que también aumentaron a la vez la duración de su estancia fuera del país y los riesgos de la travesía de la frontera. Por consiguiente hubo, en los años 1990, un aumento significativo de la población indocumentada en los Estados Unidos. 
Este artículo analiza la emergencia de un sistema regional de integración informal entre México y los Estados Unidos, movido por los mismos inmigrantes, así como por los que sacan provecho de la inmigración irregular, y no por los protagonistas institucionales. Esta integración informal es el resultado de dos tipos de movimientos: el de los migrantes hacia el norte de la frontera y, cada vez más, el de las remesas hacia el sur. Estas remesas alimentan también los flujos de inmigración, puesto que perpetúan las expectativas de los inmigrantes. Este artículo examina el desarrollo de esta forma paralela de integración que apareció con la ejecución del tratado de libre comercio, fuera del control de los gobiernos mexicano y norteamericano.

\section{AUTHOR}

\section{FANNY LAUBY}

Université Paris III Sorbonne Nouvelle / City University of New York 